\title{
Role of low dose danazol therapy for endometriosis related infertility and its comparison with laparoscopic fulguration in low resources
}

\author{
Urvashi Verma ${ }^{1}$, Shivani Singh ${ }^{2 *}$, Mukesh Chandra ${ }^{1}$, \\ Richa Singh ${ }^{1}$, Mukul Chandra ${ }^{1}$, Aruna Goel ${ }^{1}$
}

\author{
${ }^{1}$ Department of Obstetrics and Gynecology, S. N. Medical College, Agra - 282002, Uttar Pradesh, India \\ ${ }^{2}$ Department of Obstetrics and Gynecology, Era's Medical College and Hospital, Lucknow - 226003, Uttar Pradesh, \\ India
}

Received: 21 November 2013

Accepted: 15 December 2013

\author{
*Correspondence: \\ Dr. Shivani Singh, \\ E-mail: bundela.shivani@gmail.com
}

(C) 2014 Verma U et al. This is an open-access article distributed under the terms of the Creative Commons Attribution Non-Commercial License, which permits unrestricted non-commercial use, distribution, and reproduction in any

\begin{abstract}
Background: The objective was to study the role of laparoscopic fulguration and danazol therapy for endometriosis in case of infertility followed by comparison of both therapies.

Methods: The present cross-sectional study was conducted in the department of obstetrics and gynecology SN Medical College Agra. Over the period from December 2010 to November 2013. Symptomatic women $(n=50)$ of age group 20-39 yrs coming to gynecology OPD were selected for study group. The study group was subjected to detailed history, physical examination laboratory test, ultrasound examination, and laparoscopy. Then 50 patients were allotted for laparoscopic fulguration and 50 for danazol treatment.

Results: Out of 100 on transvaginal sonography, $10 \%$ of patient have cyst $<2 \mathrm{~cm}$ size and $20 \%$ have $>2 \mathrm{~cm}$ size, rest $70 \%$ have normal scan. On laparoscopy $52 \%$ of patient have red lesion, $16 \%$ have bluish black lesion, $20 \%$ have yellow brown lesion rest $22 \%$ have normal findings. On danazol therapy pelvic pain and dysmenorrhoea was relieved in $64 \%$ and $52 \%$ conceived .on laparoscopic fulguration symptom were relieved in $69 \%$ and $60 \%$ conceived.

Conclusions: Based on this study it can be concluded that choice of therapy depend on age of patient, duration of infertility, physical findings, goal of surgery, experience of surgeon and most important the availability of resources. In this study result was comparable.
\end{abstract}

Keywords: Endometriosis, Infertility, Danazol, Fulguration

\section{INTRODUCTION}

Endometriosis is a disease in women of reproductive age group characterized by the presence of endometrial gland and stroma outside the uterus causing pain and infertility. ${ }^{1} \quad$ The prevalence of asymptomatic endometriosis is $1-7 \%$ in women serving elective sterilization, $12-32 \%$ among women of reproductive age group with pelvic pain, 9-50\% in infertile women and approximately $50 \%$ among teens with chronic pelvic pain or dysmenorrhoea ${ }^{2}$ the overall prevalence of endometriosis in reproductive aged women probably is between $3 \%$ and $10 \%$. Endometriosis is strongly associated with infertility between $20-40 \%$ infertile women have the disease. The overall prevalence of endometriosis is greater in infertile women than in fertile women. The multiple effect of danazol produces a high androgen and low oestrogen environment that doesn't support the growth of endometriotic tissue and the amenorrhea that is produced prevents the new seeding of implants from uterus into peritoneal cavity. ${ }^{3}$ Fulguration is a procedure that involve using a high voltage electric current to destroy tissue.

\section{METHODS}

The present cross-sectional study was conducted in the department of obstetrics and gynecology SN Medical 
College Agra. Over the period from December 2010 to November 2013 symptomatic women $(n=100)$ of age group 20-39 years coming to gynecology OPD were selected for study group. The study group was subjected to detailed history, physical examination laboratory test, ultrasound examination, and laparoscopy. Then 50 patients were allotted for laparoscopic fulguration and 50 for danazol treatment. After analyzing the data the result were compared.

\section{RESULTS}

Mean age in both groups was $(28 \pm 10)$ with primary and secondary infertility both. Most of the women in study were nullipara (48\%). pelvic pain and dysmenorrhoea were the most common symptom.

In danazol group (A) TVS findings were normal in 64\% of cases. Endometriotic cyst $<2 \mathrm{~cm}$ size in $12 \%$ of cases and endometriotic cyst $>2 \mathrm{~cm}$ size in $24 \%$ of cases. In laparoscopic fulguration group (B) TVS findings were normal in $76 \%$ of cases. Endometriotic cyst $<2 \mathrm{~cm}$ size in $8 \%$ of cases and endometriotic cyst $>2 \mathrm{~cm}$ size in $16 \%$ of cases.

Table 1: Distribution of patient according to profile.

\begin{tabular}{|lll|}
\hline Patient profile & $\begin{array}{l}\text { Group A } \\
\text { (Danazol) }\end{array}$ & $\begin{array}{l}\text { Group B } \\
\text { (Laparoscopic } \\
\text { fulguration) }\end{array}$ \\
\hline Mean age (years) & $28.6 \mathrm{yrs}$ & $27.6 \mathrm{yrs}$ \\
\hline Type of infertility & & \\
\hline Primary & $24(48 \%)$ & $22(44 \%)$ \\
\hline Secondary & $26(52 \%)$ & $28(56 \%)$ \\
\hline & Class III- & Class III- \\
Socioeconomic status & $20(40 \%)$ & $28(44 \%)$ \\
\cline { 2 - 3 } & Class IV- & Class IV- \\
\hline Menstrual patter & $30(60 \%)$ & $22(56 \%)$ \\
\hline Normal & $16(32 \%)$ & $24(48 \%)$ \\
\hline Menorrhagia & $24(48 \%)$ & $18(36 \%)$ \\
\hline Dysmenorrhea & $10(20 \%)$ & $8(16 \%)$ \\
\hline
\end{tabular}

Table 2: Distribution of patients according to TVS findings.

\begin{tabular}{|llll|l|}
\hline TVS findings & \multicolumn{2}{l|}{$\begin{array}{l}\text { Group-A } \\
\text { (Danazol } \\
\text { therapy) }\end{array}$} & \multicolumn{2}{l|}{$\begin{array}{l}\text { Group-B } \\
\text { (Laparoscopic } \\
\text { fulguration) }\end{array}$} \\
\hline & No. & $\%$ & No. & $\%$ \\
\hline Normal & 32 & $64 \%$ & 38 & $76 \%$ \\
\hline $\begin{array}{l}\text { Endometriotic } \\
\text { cyst < } 2 \text { cm }\end{array}$ & 6 & $12 \%$ & 4 & $8 \%$ \\
\hline $\begin{array}{l}\text { Endometriotic } \\
\text { cyst }>2 \text { cm }\end{array}$ & 12 & $24 \%$ & 8 & $16 \%$ \\
\hline Total & 50 & $100 \%$ & 50 & $100 \%$ \\
\hline
\end{tabular}

Table 3: Distribution of patients according to laparoscopic findings.

\begin{tabular}{|l|l|l|}
\hline $\begin{array}{l}\text { Laparoscopic } \\
\text { findings }\end{array}$ & $\begin{array}{l}\text { Group A } \\
\text { (Danazol } \\
\text { therapy ) }\end{array}$ & $\begin{array}{l}\text { Group B } \\
\text { (laparoscopic } \\
\text { fulguration) }\end{array}$ \\
\hline & $\mathrm{n}(\%)$ & $\mathrm{n}(\%)$ \\
\hline Normal & $22(44 \%)$ & $0(0 \%)$ \\
\hline Red lesions & $18(36 \%)$ & $34(68 \%)$ \\
\hline Bluish black lesions & $6(12 \%)$ & $10(20 \%)$ \\
\hline Yellow brown lesions & $4(8 \%)$ & $6(12 \%)$ \\
\hline Total & $50(100 \%)$ & $50(100 \%)$ \\
\hline
\end{tabular}

In group A, normal laparoscopic findings were found in $44 \%$ of cases. Red flame lesions in $20 \%$ of cases, petechial lesions in $12 \%$ of cases, bluish black in $12 \%$ of cases, glandular lesion in $4 \%$ of cases, yellow brown in $8 \%$ of cases. In group B red flame lesions in $44 \%$ of cases, petechial lesions in $12 \%$ of cases, bluish black in $12 \%$ of cases, glandular lesion in $12 \%$ of cases, yellowish brown in $12 \%$ of cases. In group A after danazol therapy associated symptoms were relieved in $64 \%$ of cases. In group B after laparoscopic fulguration associated symptoms were relieved in $60 \%$ of cases. In group A $52 \%$ of cases were conceived and $36 \%$ of cases were not conceived and $12 \%$ were lost to follow up. In group B, $60 \%$ of cases were conceived and $32 \%$ of cases were not conceived and $8 \%$ were lost to follow up.

Table 4: Distribution of patients according to symptoms relieved after therapy danazol laparoscopic fulguration.

\begin{tabular}{|lllll|}
\hline $\begin{array}{l}\text { Symptoms pelvic } \\
\text { pain, dysmenorrhoea }\end{array}$ & \multicolumn{2}{l}{$\begin{array}{l}\text { Group-A } \\
\text { (Danazol } \\
\text { therapy) }\end{array}$} & \multicolumn{2}{l|}{$\begin{array}{l}\text { Group-B } \\
\text { (Laparoscopic } \\
\text { fulguration) }\end{array}$} \\
\hline & No. & $\%$ & No. & $\%$ \\
\hline Relieved & 32 & $64 \%$ & 30 & $60 \%$ \\
\hline Not relieved & 4 & $8 \%$ & 8 & $16 \%$ \\
\hline $\begin{array}{l}\text { Normal } \\
\begin{array}{l}\text { No associated } \\
\text { symptoms) }\end{array}\end{array}$ & 14 & $28 \%$ & 12 & $24 \%$ \\
\hline Total & 50 & $100 \%$ & 50 & $100 \%$ \\
\hline
\end{tabular}

$P \geq 0.70$

Table 5: Distribution of patients according to pregnancy rate after danazol / laparoscopic fulguration.

\begin{tabular}{|lllll|}
\hline Pregnancy rate & \multicolumn{2}{l}{$\begin{array}{l}\text { Group-A } \\
\text { (Danazol } \\
\text { therapy) }\end{array}$} & \multicolumn{2}{l|}{$\begin{array}{l}\text { Group-B } \\
\text { (Laparoscopic } \\
\text { fulguration) }\end{array}$} \\
\hline No. & $\%$ & No. & $\%$ \\
\hline Conceived & 24 & $48 \%$ & 30 & $60 \%$ \\
\hline Not conceived & 18 & $36 \%$ & 16 & $32 \%$ \\
\hline Lost to follow up & 8 & $16 \%$ & 4 & $8 \%$ \\
\hline Total & 50 & $100 \%$ & 25 & $100 \%$ \\
\hline
\end{tabular}

$P \geq 0.70$ 


\section{DISCUSSION}

After danazol therapy symptoms (pelvic pain, dysmenorrhoea) were relieved in $64 \%$ of women and in Group B $60 \%$ women only. In group A $52 \%$ of women conceived and in group B $60 \%$ women conceived. These result was comparable to study done by Greenblatt $\mathrm{RB}^{4}$ (1980) and Dmouski WP ${ }^{5}$ (1982) used danazol for the treatment of endometriosis associated infertility.

Table 6: Results of danazol treatment in various studies.

\begin{tabular}{|lll|}
\hline Study & $\begin{array}{l}\text { Improvement in } \\
\text { associated symptoms }\end{array}$ & $\begin{array}{l}\text { Pregnancy } \\
\text { rate }\end{array}$ \\
\hline Greenblatt RB & $75 \%$ & $50 \%$ \\
\hline Dmouski WP & $80 \%$ & $70 \%$ \\
\hline $\begin{array}{l}\text { Present study } \\
\text { (group A) }\end{array}$ & $64 \%$ & $52 \%$ \\
\hline
\end{tabular}

Results of fulguration were comparable to study done by Hasson et al. ${ }^{6}$ and Nowroozik Chase JS, Check JH et al. ${ }^{7}$

Table 7: Results of laparoscopic fulguration in various studies.

\begin{tabular}{|ll|}
\hline Study & Pregnancy rate \\
\hline Hasson et al. & $75 \%$ \\
\hline Nowroozik et al. & $60.8 \%$ \\
\hline Present study (group B) & $60 \%$ \\
\hline
\end{tabular}

Table 8: Results of danazol and laparoscopic fulguration in various studies.

\begin{tabular}{|lll|}
\hline Study & $\begin{array}{l}\text { Pregnancy rate } \\
\text { Danazol treated } \\
\text { n(\%) }\end{array}$ & $\begin{array}{l}\text { Laparoscopic } \\
\text { fulguration }\end{array}$ \\
\hline Guziek DS et al. $^{8}$ & $91(74 \%)$ & $133(68.3 \%)$ \\
\hline Present study & $13(52 \%)$ & $15(60 \%)$ \\
\hline
\end{tabular}

The results were comparable to other study. Based on this discussion it can be concluded that results are comparable for danazol therapy and laparoscopic fulguration. But the choice of therapy depends on history, patient age, duration of infertility, physical findings, goals of surgery and other factor of infertility.

- Some of the implants are suspected deep, small and not visible on laparoscopy.

- Patients with unexplained infertility.

- The patient with endometriosis and pelvic pain does not desire an immediate pregnancy.

- Patient belongs to low socioeconomic status especially in developing countries.

- Experienced laparoscopic surgeon's nonavailability.
- Cost-effective treatment is needed.

\section{CONCLUSIONS}

Endometriosis is an ovarian steroid dependent, multifocal disease. Some of the implants are small and deep and thus not visible or laparoscopy. This fact limit the effectiveness of any sort of laparoscopic treatment aimed at totally eliminating endometriosis. Laparoscopic surgeries are not affordable by many patients because of its cost as well as fear of surgery especially in countries like ours. Low dose danazol therapy does not have major side effects, not require too much monitoring that's why can be given at community and primary health centers (CHCs, PHCs) to the population residing in slums and villages.

Funding: No funding sources

Conflict of interest: None declared

Ethical approval: The study was approved by the institutional ethics committee

\section{REFERENCES}

1. Speroff L, Glass RH, Kasc NG. Clinical Gynaecologic endocrinology and infertility 6th ed. Baltimore: Lippincot Williams \& Williams; 1973: 152-71.

2. D. Hooghe TM Bambara CS, Cornille FJ, et al. prevalence of endometriosis. Fertile Steril. 1989;52;63-7.

3. Arnold DL, Nera EA, Stapely R et al. Prevelence of endometriosis. Review and evaluation, Fund Appl Toxicol. 1996;31:42-55.

4. Greenblatt RB. Danazol in the treatment of infertility. Drug. 1980May;19(5):362-9.

5. Dmouski WP, Danazol in the treatment of endometriosis and infertility. Prog Clin Biol Res. 1982;112ptB;167-86.

6. Hasson HM. Electrocoagulation of pelvic endometriosis lesions with laparoscopic control. Am J Obstet Gynaecol. 1992;3:721-30.

7. Nowroozik, Chase JS, Check JH, Wuch. A comparison of Danazol and Conservative surgery for the treatment of infertility due to mild or moderate endometriosis. Fertil Steril. 1983;40:580.

8. Guzick DS, Rock JA. A comparison of danazol and conservative surgery for the treatment of infertility due to mild or moderate endometriosis. Fertil Steril. 1983 Nov;40(5):580-4.

DOI: $10.5455 / 2320-1770$. ijrcog20140313

Cite this article as: Verma U, Singh $S$, Chandra M, Singh R, Chandra M, Goel A. Role of low dose danazol therapy for endometriosis related infertility and its comparison with laparoscopic fulguration in low resources. Int J Reprod Contracept Obstet Gynecol 2014;3:67-9. 